Journal of Social Sciences 2 (2): 48-53, 2006

ISSN 1549-3652

(C) 2006 Science Publications

\title{
The Role of an Environmental Management in Improving of Competition in Manufacturing Companies
}

\author{
Talal M. Bataineh \\ Tafila Technical University, P.O. Box 179, Tafila, Code (66110), Jordan
}

\begin{abstract}
Environmental management approach is the way that used to integrate the environmental considerations in the management operation and decision making operation in under developing countries, especially in this conditions, which are full of competition and continuously changes. So, implementation of environmental management approach is a very important action, because it has a positive effects on the function of the entity (productivity, Trading, Accounting, financial, human resources. and researching and development), also it has a positive effects on the managerial performance it self. Before the decision of implementing an environmental management approach, it must make a cost-benefit analyzing in order to ensure from its appraisal. The successful implementation of environmental management approach needs the support of the high managers at the entity; also it needs the efforts of all levels in the entity, in addition to all needed resources. The environmental laws must contain the ways of implementing of the environmental management approach in the entity. To have an efficient result, it is important for the entity to combine the environmental management system with the total quality management system.
\end{abstract}

Key words: Environmental management system, managerial performance, manufacturing companies

\section{INTRODUCTION}

With in the increased interesting in the environment and with in the appearance of continuous it self responsible from the environmental damages, so many laws took place to keep the environment empty of pollution, also this encourage the managers in many companies to implement an environmental management on their work and with in their companies system and law ${ }^{[1]}$.

On the other hand, Companies used environmental management to achieve a competitive advantage especially in the time where is a big challenge that faced companies to reach a high level of product quality. So an environmental management is taken a place in the companies as one of the most important approaches to continue in the market and to develop its products, especially in today's market, which depends mainly on speed, development, multi customer alternatives, opened markets and free trade markets ${ }^{[2]}$.

In this study the researcher is trying to focus on the theoretical background of the environmental management, the reasons that encourage the companies to take it and the whole of it in developing the competitive advantage of the manufacturing companies, which allow them to continue in various changed environment.

The meaning of environmental management: There are many definitions for environmental management
* In the united nation report ${ }^{[3]}$ the definition focus on putting the planes and the environmental policies that evaluate the environmental results of all the stages of producing operation starts from the purchasing of raw materials and endings in the finished products, also, it contains the controlling procedures that must take place, with caring about costs and the way that the resources is used to prevent the pollution.

* The technical Committee of the organization of standard (207) said that the environmental management is a part of a full management system that includes the organization structure, planning activities procedures and the resources that used to develop and achieve the auditing and protect the environment policies ${ }^{[4]}$.

* Thomas et al. ${ }^{[1]}$ said that it is the structure of the entity, responsibilities, policies , practicing, procedures, actions and the resources that used in the protecting of the environmental and in the managing of environment, also it contains the programs to manage and protect the environment .

* But Henning pointed that the environmental management is the public policies that used to protect the public actions. Also, he said that it is as any other management, the people helping each other's on it to achieve a group of planned objectives $^{[5]}$.

Finally, the researcher defines the environmental management as follows; it is apart of a full management system that contains the administrative aspects 
planning, organizing, directing and controlling. Also, it's an operation of a human action used to control the activities that affect the environment and to achieve the company's goals and policies in a planned program, also to make a continuous audit tins for the operation of the company and for its products and services in order to develop its environmental achievements.

The relationship between the environmental management and the sustainable development: The development in environmental management go on with the development in laws that related to the environment and the increased international interesting in the problems of environment that caused by pollution. This development leads to interest in actions that will achieve the complementation between economic developments and the environmental considerations, all of these leads to the definition of sustainable development. Concept, which defined on the report of international committee for environment and development 1987 as, " to achieve the present needs of the people without effecting on the future needs ${ }^{[6]}$.

The report encourages the manufacturing Companies to give the environment more interesting and to put it within its planning and to establish special departments for the environment to deal with the problems that related to the it.

This report also encourages (ICC) to put the work agreement for sustainable development which includes 16 principles that dealing with environmental management, also it includes important aspects that related to environmental management system $^{[4]}$, also, Rio de Janiero conference in 1992 consider unplanned production operations and the wrong ways of using resources are the main reason of environmental damages. So the environmental management and the knowledge in resources using-(Nature, human being and economy)-are the most important policies of sustainable development which focuse on keeping this resources available protect the environment from pollution so the related parties focus the development concepts that related to the production and environmental protecting which leads to the benefit of the factory, increase its profit and protect the environment ${ }^{[5]}$.

Also, In this conference interesting in environment increased internationally by issuing a series of International specifications related to the environment, which is ISO 14000 in 1996 which improve and simplify trading, this specification comes as a result of efforts to create one international specification that allows to free trading and to protect the environment at the same time, Also the other objectives of this international environmental management are:

A. To put procedures that identifies the rules, the procedures and the Social pressures.
B. To encourage Companies to manage and evaluate the environmental action that related to its activities, products and service.

C. To improve the environmental actions in manufacturing.

D. To achieve a complement between national and international standards so as to simplify trading.

E. To increased creditability.

F. To find one language for environmental management internationally ${ }^{[4]}$

The requirements of environmental management according to ISO 14000: The environmental management system includes five components according to the 207 committee that related to international standards organization:

* Environmental policy.

* Planning.

* Implementation and operation.

* Checking and Corrective actions.

* Management Review.

These five components are the requirements of environmental management system that may apply on different kinds and size of environmental management system:

Environmental policy: Which include the planes, principles and goals of the managers of the companies toward the environment, all these to ensure from the following:

A. The suitability of its policy to the environmental affects which Come as a result of the activities, products and services of the Entity.

B. The extent of commitment in continuous improvement and Prevention from pollution.

C. The extent of conformity with laws, requirements and Legislations that related to the entity operations.

D. The availability of a frame for auditing the environmental goals.

E. Ensuring from documentation and implementation operation that used to protect the environmental policy.

F. Ensuring from informing to the Audience ${ }^{[4]}$.

Planning: This stage starts by restricting the most important sides of environmental operation, after that, it identifies the law's requirement that suitable for the entity, then it develops the goals of the environmental effects and prepares the programmers to achieve with in the available information ${ }^{[4]}$.

Environmental aspects: The environmental aspects and the environmental effects combined in cause and effect relationship, the environmental aspects are a part of the entity's activity and its products or services which is considered the source of the environmental impact which is come as result of changing in environment. 
Legal and other requirements: The entity must identify the legal requirements of the environment. Also, specification ISO 14001 put in its supplement the other requirements that may contain codes and manufacturing implementations, agreements with the public Authority and un systematic advices.

Objectives and targets: The specification appointed to the target as the comprehensive environmental objective which resulted from the environmental policy which the entity wanted to a achieve and which can assess wherever achieved. Also, the environmental objectives must apply on all the departments of the entity that may need it.

Environmental management program: This is a final stage of planning, in this program the entity must put the objectives and distribute the responsibilities to the different levels of the management; also it must put a timetable to achieve its objectives and targets.

Implementation and operation: The successful implementation needs participation from all the employees in the entity. This stage has seven steps.

\section{Structure and responsibility}

A. Building an efficient environmental management by identifying Roles, responsibilities and duties in the entity.

B. Obtaining the necessary resources to implement and control the environmental management system.

C. The management must give authority to representative in order to:

* Put the requirements of the environmental management system, to implement it and to keep it with specification.

* Prepare and supply high managers with the reports about the environmental management system in order to improve it.

Training and raising an environmental wariness: The entity must:

A. Identify the training needs.

B. Putting special programs for the action that have a dangerous

\section{Environmental effects}

C. Putting the necessary procedures so as to increase wariness between its employees.

This includes:

* The importance of implementing the environmental policy and the other environmental management system requirements.

* The expected dangerous environmental effects.

* The responsibility of the employees and their role in the implementing of environmental policy and environmental management system.
* Identifying the persons who have an excellent experience with a high level education.

D. Changing person whose work has dangerous environmental effects.

Communication: The entity must simplify communication between all internal and external parties of the entity in order to control any environmental problem.

Environmental management system documentation: The entity must keep all the information about the environmental management system and it must simplify the way to obtain any information.

\section{Documentation control}

A. The company must put all the procedures to control all the Documents that related to the environmental management System that is to ensure from

* It's finding in its places.

* Auditing it from professional person.

* Obtaining the documents wherever needed.

* Isolating the omitted document from usage.

B. To keep the documents in a legal systematic way with dates.

C. To fix the procedures and responsibilities so as to ensure from implementing an efficient management system.

Operation control: Operation control is the basic requirement to implement environmental management system, so the entity must identify activities that will create dangerous environmental aspect, which go on with its objective and targets.

Emergency preparedness and response: The entities are working in uncertainty conditions, so it's important for the entity to keep helpful procedures to be implied in emergency conditions ${ }^{[4]}$.

Checking and corrective actions: Checking and corrective are the basic activities of the environmental management system, which help entity to work on the planed program, this requirement includes for activities:

A. Follow-up and assessment: It is one of the most important Ways in environmental performance.

B. Looking for unsuitable conditions, finding its reasons, implying the corrective procedures and documenting these Procedures.

C. Protecting the recordation of environmental performance ${ }^{[4]}$.

D. Environmental auditing: It is a managerial tool that includes a continues objective

* Evaluation for environmental management in order to protect the environment through;

* Simplifying of an environmental practicing.

* Ensuring from a biding by entity policy that include an organized requirements. 
Management review: It is the final requirement of environmental management system, which includes the following:

A. Ensuring of the suitability of this system by implying a continuous auditing.

B. Collecting necessary information for the valuation operation.

C. Documents the auditing procedures.

D. Seeing the need for environmental policies and objective changes.

Auditing includes the following:

* The operations and the results of the Auditing.

* The achievement of objectives and targets. .

* The elasticity of system in different conditions.

* The opinions of persons who concerned with environment $^{[4]}$

Specifications also include the important tools that needed to imply to The Environmental Management System:

A. Estimation way of product cycle life that might be used in Analyzing of environmental aspect of products, services and the entity's activities.

B. Environmental disclosure behavior, which introduce the needed information about products and services of the entity.

C. The procedures of environmental performance evaluation for the products and activities of the entity in order to improve the environmental performance.

D. Procedures needed in implementing environmental auditing standards.

Implementing of environmental management in entities between self-oriented and external pressure: Implementing of environmental consideration on the managerial operation in the entity is a voluntary action, because it creates benefits to the entity it self as, cost reduction production increasing, product quality and profitability improvement all of theses. Increase the competitive advantage of the entity; also the environmental management system achieves environmental and social benefits ${ }^{[4,7]}$ :

A. Protecting all the environmental systems of the nature.

B. Using on efficient resources as: lands, water and capacity.

C. Decreasing the quantity of litter and reusing of resources.

D. Decreasing the effects on the heath and security of human being.

E. Improving human healthy in work and society.

F. Increasing human healthy in work and society.

G. Implementing of environmental management may take apart in correcting the problem of thermal retention and ozone whole threatens the future of new generation.

In These days implementing of environmental management approach is compulsory action, because there are an external groups interesting in the implementation of this approach as:

Customers, lenders, governmental committee and others, so, the external resources of pressure that leads the entity to interest in the environmental action are:

Governmental requirements: The most important way to force the entity in the environmental. Performance is the Governmental Legislations, so the entity is trying to care about the environmental considerations in order not to face a legal responsibility.

Customers: Environmental considerations are one of the most important factors that influence the customer habits, so customers are always trying to purchase products that have no environmental effects, this behavior lead to the appearance of what called, Green products, Ethical products, friendly products, ozone friendly and other names focusing on environment.

In the same time there are many society encourage customer to use products without environmental effects, also they encourage customers to use their purchasing power as an economic vote to encores products to produce the products that will not cause a damage to the environment.

Owners, investors and lenders: Owners, Investors and Lenders are always trying to obtain information about the entities environmental performance, because they have a big confidence if there is a bad environmental practices in the entity, liabilities and risks, will be increased also the profits of the entity will be decreased ${ }^{[8]}$. Also, Sturm et al. ${ }^{[9]}$ points that environmental management system is important for entity because this will tranquilize the investors about the performance of the entity in the market and about its ability to compete in international markets, all of this will lead to improve the quality of its products.

Contractual requirements: The management of supplier is a core center factor in external environmental managements so organizations encourage the suppliers to achieve a good environmental performance; also they are trying to participate him in designing operation. Also they may force them to follow the specification of environmental management system ISO 1400 so it is become necessary to force on the suppliers to improve the environmental performance ${ }^{[4]}$. So the caring of entities to the environmental performance is appeared by discussing the international interesting to get the ISO 14000 certificate as follows:

A. Countries that registered in ISO 14000: The number of entities that registered to ISO 14000 is 22897 entities till year 2000, these entities distributed into 98.

* Countries, this form an increased of 8791 entities comparing with the prior year at apercontage of 
$3.62 \%$. Japan is the first Country, then England, Suede, Germany and Australia.

* Table 1 includes the numbers of entities in these countries and the percentage of them comparing with other countries in all over the world ${ }^{[4]}$

B. Obtaining ISO 14000 by Arab countries: The Arab entities that registered on ISO 14000 till 2000 are 169 entities distributed on 12 countries and form $74 \%$ of the whole world countries. Table 2 includes description to these entities.

\begin{tabular}{|c|c|c|c|}
\hline & Countries & $\begin{array}{l}\text { Number of registered } \\
\text { Till December } 2000\end{array}$ & $\begin{array}{l}\text { The percentage } \\
\text { comparing with } \\
\text { Other Countries }\end{array}$ \\
\hline 1. & Japan & 5556 & $24.2 \%$ \\
\hline 2. & England & 2534 & $11.1 \%$ \\
\hline 3. & Suede & 1370 & $5.9 \%$ \\
\hline 4. & Germany & 1260 & $5.5 \%$ \\
\hline 5. & Australia & 1049 & $4.6 \%$ \\
\hline
\end{tabular}

Table 2: Arab registered countries on ISO 14000

\begin{tabular}{llc}
\hline & Countries & $\begin{array}{c}\text { Number of registered } \\
\text { Till December 2000 }\end{array}$ \\
\hline 1. & Egypt & 78 \\
2. & United Arab Emirate & 48 \\
3. & Jordan & 16 \\
4. & Saudi Arabia & 6 \\
5. & Lebanon & 5 \\
6. & Morocco & 4 \\
7. & Syria & 3 \\
8. & Tunis & 3 \\
9. & Oman & 2 \\
10. & Bahrain & 2 \\
11. & Palestine & 1 \\
12. & Qatar & 1 \\
\hline \multicolumn{2}{l}{ Source: Azawe }
\end{tabular}

Environmental management and the competence of manufacturing entities: The competitive advantage is an important factor in the entity, it open doors for it to achieve an excellent performance over other entities by following difference types of strategies. So the successful implementation of environmental management in the entity allows it to increase its competitive ability in many sides:

Firstly: Increasing productivity and decreasing costs: When entity has a big quantity of products with little costs it can put a low price than other entities, this strategy will increase its sales and increase its market area. Also, even the entity sales at the same price of entities it will achieve a higher contribution margin than the other entities $^{[10]}$.

The role of environmental management in this case is to decrease the costs and to increase the productivity though:

A. A good use of recourses and capacity.

B. Decreasing the ratio of defective in production.
C. Increasing the efficiency of the employees by training programs.

D. Keep an efficient relationship with the suppliers ${ }^{[10]}$

E. Increasing the productivity of the employees by improving the work environment as a suitable building which studies proved that it increased the productivity of employees to $15 \%^{[7]}$

F. Availability in costing as a result of:

* Decreasing in the consumption of capacity and other resources.

* Recycling of litters.

* Selling of up normal production.

* Decreasing the cost of transportation and storage by decreasing raw materials and capacity.

* Decreasing other financial costs as a result of implementing of environmental performance

G. Financial abundance in other sides as:

* Investing in working capital by reducing production requirements, as resources and capacity, the entity will invest less in working capital.

* Investing in fixed capital, which means decreasing investment in the dangerous effects of environment, because entity has already implemented environmental management system.

* Tax allowance as a result of decreasing the environmental effects.

* Decreasing the training course costs on long-term.

* Decreasing costs by committing in the legal requirements of environment.

* Decreasing the costs of capital, which means the decreasing in environmental risks of partners and investors, will lead to decrease in the interest rate of internal and external capital.

* Obtaining financial benefits as a result of implementing of environmental management, this benefits like a law interest rate on loans and other benefits from the Government ${ }^{[9]}$.

Secondly: Achieving marketing benefits: Entity that work on products that not harm the environment it will obtain the most important parts of markets, because this entity helps customers to achieve their objectives and this will increase the competitive advantage of the entity $^{[4]}$.

In this case the environmental disclosure is very important for the entity, because it will lead to improve the position of the entity in the eyes of the customer which will encourage customers to consume the products of this entities comparing with other entities, which don't complement with the environmental considerations.

In this subject a Germany study a pointed that the market of Sony Company this decreased to $11 \%$ which producting T.V with 57\% increasing Nokia company this happened when customer magazine published an evaluation about television, this evaluation considered Nokia the best in environmental consideration ${ }^{[4]}$. 
Also, implement of implementation management sustain the position of the entity in the international market, this happen by taking the suitable procedures for the customers in other markets and countries, these procedures will increase the competitive advantage of this kind of entities ${ }^{[11]}$.

Thirdly: Improving the managerial performance: Many studies proved that the implementation of environmental management approach achieve many benefits that effect positively in the improvement of the management performance in the entity and the main aspects of this improvement are ${ }^{[4]}$

A. Increasing the satisfaction of employees: Encouraging employees to take apart in the implementation of environmental management requirements will increase their interesting in environmental considerations and increase their power.

B. Improving the followed procedures.

C. Benefiting from the auditing of internal environmental systems, which leads to continuous improvement in the entity performance.

D. Encouraging the coordination between the different departments of the entities and improving the communication.

E. Giving new employees full information about their work, this as a result of a clear documentation of the responsibilities.

F. Complementing of the managerial systems: The implementation of environmental management supplying the entity with a systematic approach that will affect the other departments on the entity.

\section{REFERENCES}

1. Al-Saka, AL-said Ahmad, 1999. Environmental Performance Management. Public Management Institute, Al Ryad, Vol. 2.

2. Al-Salame, A., 2002. The Management of Excellence-The Forms and Technical in the Knowledgement Time. Dar Ghareeb for Publishing, Cairo.

3. United Nation, 1996. Environmental management in the pulp and paper industry. Technical Report, UNDP, No. 34, Paris.

4. Al-Azawe, M.A.A., 2002. Environmental and Quality Management System ISO 9000 and ISO 14000. First Edn., Dar Weal, Amman.

5. Henning, D. et al., 1989. Managing the Environmental Crisis. Duke University Press, London.

6. World Commission on Environment and Development (WCED), 1989. Our Common Future. Oxford University Press, Oxford.

7. United Nations, 1997. Environmental Management on Industrial Estates, Technical Report, UNDP, No. 39, Paris.

8. Gale, G.D., 2001. Developing of auditing to face the current problems and the challenges of third millennium. AL Dar Al Jameah, Cairo.

9. Sturm, A. et al., 1998. ISO 14001 Implementing an environmental management system. Ellipson Ltd., Bassel.

10. Mestafa, A.S., 1999. The management of production and operations in manufacturing and services. Fourth Edn., Cairo.

11. North, K., 1992. Environmental Business Management International Labor Organization, Geneva. 